\title{
Laktancij in spis O smrtih preganjalcev
}

\section{Milan Lovenjak ${ }^{*}$}

Spis z naslovom »knjiga Lucija Cecilija izpovedovalcu Donatu o smrtih preganjalcev« je ohranjen v enem samem rokopisu iz 11. stoletja, ki ga je aprila 1678 - skupaj z okrog 250 drugimi - odkril opat Raymond de Foulhac v benediktinski opatiji St. Pierre v Moissacu v Akvitaniji. ${ }^{1}$ Rokopis je bil odkupljen za knjižnico Jeana-Baptistea Colberta, takratnega prvega ministra pod Ludvikom xIV., leto dni kasneje pa ga je $\mathrm{z}$ obsežnim komentarjem izdal eden vodilnih zgodovinarjev takratnega časa in bibliotekar omenjene knjižnice Étienne Baluze. ${ }^{2}$ Avtorstvo spisa, ki ga je označil za auro contra aestimandus, je brez sence dvoma, ali kot je zapisal, extra omnem controversiam, pripisal učitelju govorništva in znamenitemu krščanskemu piscu Luciju Ce(ci) liju Firmijanu Laktanciju, ${ }^{3}$ o katerem pravi Hieronim, da je bil največji govornik svojega časa ${ }^{4}$ in da je poleg številnih drugih del napisal tudi »knjigo o preganjanju«:

* Filozofska fakulteta Univerze v Ljubljani, Aškerčeva 2, 1000 Ljubljana; milan.lovenjak@ff.uni-lj.si

1 Članek je nastal v okviru raziskovalnega programa Slovenska zgodovina (P60235), ki ga sofinancira Javna agencija za raziskovalno dejavnost Rs.

2 Miscellaneorum liber secundus (1679), 1-46 s komentarjem na str. 347-463. Rokopis je v kodeksu s skupno 200 listi, na hrbtu pa je s tiskanimi črkami odtisnjen naslov »Lactantius de persecutione«, znak Colbertove knjižnice (z okrajšavo B. C.) in številko 1297. Colbertovo zbirko rokopisov je njegov vnuk leta 1731 prodal Bibliothèque Royale, danes je to Francoska nacionalna knjižnica (Bibliothèque nationale de France). Tam je shranjen pod oznako Ms Lat. 2627, digitalizirana verzija besedila pa je od 2013 dostopna na spletu.

3 O Laktancijevem avtorstvu piše Baluze izčrpno v predgovoru (Praefatio p. I) in v komentarju (Notae ad Lactantium; Miscellaneorum liber secundus, 351-352).

4 Chronica ad a. Abr. 2833 (317): „Crispus et Constantinus fili Constantini et Licinius adulescens Licini Augusti filius Constantini ex sorore nepos Caesares appellantur - quorum Crispum Lactantius Latinis litteris erudivit vir omnium suo tempore eloquentissimus, sed adeo in hac vita pauper, ut plerumque etiam 
Firmianus, qui et Lactantius, Arnobii discipulus, sub Diocletiano principe accitus cum Flavio Grammatico, cuius de Medicinalibus versu compositi exstant libri, Nicomediae rhetoricam docuit, et penuria discipulorum, ob Graecam videlicet civitatem, ad scribendum se contulit. Habemus eius Symposium, quod adolescentulus scripsit;

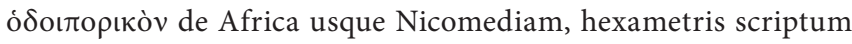
versibus, et alium librum, qui inscribitur Grammaticus, et pulcherrimum de ira Dei, et Institutionum divinarum adversum gentes libros

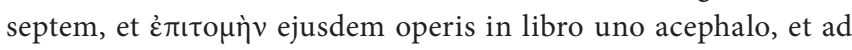
Asclepiadem libros duos, de persecutione librum unum, ad Probum Epistolarum libros quatuor, ad Severum Epistolarum libros duos; ad Demetrianum, auditorem suum. Epistolarum libros duos; ad eundem de Opificio Dei, vel formatione hominis, librum unum. Hic extrema senectute magister Caesaris Crispi, filii Constantini, in Gallia fuit, qui postea a patre interfectus est. (Hieronim, De viris illustribus 80)

Firmijan, (imenovan) tudi Laktancij, Arnobijev učenec, ki ga je skupaj z gramatikom Flavijem, avtorjem verzificiranega dela $O$ medicini, poklical cesar Dioklecijan, je v Nikomediji poučeval govorništvo in se zaradi malega števila učencev - gre namreč za grško mesto - posvetil pisanju. Ohranili so se njegov Simpozij, ki ga je napisal v mladosti,

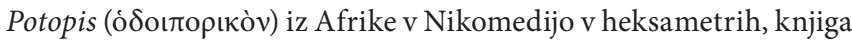
z naslovom Slovničar (Grammaticus), čudovita knjiga $O$ božji jezi (De ira Dei), sedem knjig Božjega nauka proti poganom (Divinae institutiones), izvleček istega dela $\mathrm{v}$ enem zvitku in brez naslova, dve knjigi Asklepijadu, ena knjiga o preganjanju, štiri knjige pisem Probu, dve knjigi pisem Severu, dve knjigi pisem učencu Demetriju in ena knjiga istemu $O$ božjem delu oziroma stvarjenju človeka (De opificio Dei). V pozni starosti je bil v Galiji učitelj Konstantinovega sina Krispa, ki ga je pozneje oče dal ubiti.

Krščanski Ciceron, kot so Laktancija zaradi značilnega klasičnega stila imenovali Pico della Mirandola in drugi humanisti, se je rodil v sredini 3. stoletja v Afriki. ${ }^{5}$ Po obsežnem literarnem in filozofskem

necessariis indiguerit.« (Za cezarje so bili imenovani Konstaninova sinova Krisp in Konstantin in sin cesarja Licinija in Konstantinov nečak po sestrini strani Licinij - od katerih je Krispa v latinski književnosti poučeval Laktancij, največji govornik svoje dobe, ki pa je bil v tem življenju tako reven, da so mu manjkale tudi najbolj osnovne reči.)

5 Pregledno o njegovem življenju in delu Wlosok, L. Caecilius Firmianus Lactantius, 375-404 (gl. zlasti 376, testimonia); Maver, Religiosi et profani principes, 
študiju je tudi sam postal učitelj govorništva in še kot pogan v domovini začel z literarnim udejstvovanjem. Od njegovih zgodnejših spisov, ki jih omenja Hieronim, torej del Simpozij (Symposion), Potopis (Itinerarium) in Slovničar (Grammaticus), kjer je verjetno obravnaval različna slovnična vprašanja, se ni ohranilo nič, ga je pa med 290 in 300 Dioklecijan poklical v novo prestolnico Nikomedijo v Bitiniji, kjer je poučeval latinsko govorništvo. ${ }^{6}$ Med njegovimi učenci, prejkone predvsem pripadniki dvora in uradniki, je bil morda tudi mladi Konstantin, ki je do leta 306 kot talec živel na cesarskem dvoru v Nikomediji. Njuno znanstvo bi lahko pojasnilo, zakaj ga je Konstantin kasneje, verjetno okrog 314/315, poklical v Galijo za učitelja svojega najstarejšega sina Krispa. ${ }^{7}$ V Nikomediji je Laktancij sprejel krščansko vero in doživel tudi veliko preganjanje kristjanov, ${ }^{8}$ ki se je februarja 303 začelo prav tam s prvim Dioklecijanovim ediktom, končalo pa $z$ Galerijevim tolerančnim ediktom aprila 311 in po nadaljnjih preganjanjih Maksimina Daja na Vzhodu dokončno z milanskim ediktom, ki sta ga izdala Konstantin in Licinij. ${ }^{9} \mathrm{~V}$ tem kriznem obdobju je Laktancij opustil poklic učitelja, a je verjetno ostal v Nikomediji ali nekje v bližini in se posvetil pisanju krščansko-apologetskih spisov. Kot je zapisal, je bil to zanj »boljši, koristnejši in uglednejši poklic", a naj bi mu veliko prinesel tudi prejšnji, exercitatio illa fictarum litium, da lahko $» \mathrm{Z}$ večjim bogastvom in darom govorništva slavi pravičnost «. ${ }^{10}$

58-60, in Albrecht, Geschichte, 1370-1384, podrobneje, tudi o Laktancijevih izgubljenih in apokrifnih spisih, De Decker, Bibliographie raisonée, 11-129.

6 Kot sam pravi, pa ni nikoli nastopil kot govornik (Div. inst. 3.13.12).

7 Kdaj je Laktancij prišel v Galijo, ni povsem jasno, po mnenju nekaterih že pred 310 (gl. Van Dam, Eusebius and Lactantius, 66-67). Krisp, rojen ok. leta 300, je bil sin Konstantinove prve žene ali konkubine (tako jo omenjajo viri) Minervine (PLRE 1, 602-603). V nepojasnjenih okoliščinah je bil na Konstantinov ukaz ubit spomladi (verjetno maja) $326 \mathrm{v}$ istrski Poli, ko so umrli tudi nekateri drugi člani Konstantinove družine. Poleti je bila ubita tudi cesarjeva žena Favsta, Maksimijanova hčerka, s katero se je poročil leta 307. Po nekaterih virih je nosila glavno krivdo za Krispovo smrt (podrobneje o dogodkih Bratož, Med Italijo in Ilirikom, 110-112). Laktancij je umrl ok. 325, tako da Krispove smrti ni več dočakal.

8 Gl. Div. inst. 5.2.2.

9 Za zgodovino preganjanj v času tetrarhov gl. Kuhoff, Diocletian, 246-297; Demandt, Die Spätantike, 69-72; Roberto, Diocleziano, 194-216, in Carlà-Uhink, Diocleziano, 125-150. Za preganjanja in mučence na območju Podonavja in balkanskih provinc gl. Bratož, Die diokletianische Christenverfolgung; Bratož, Med Italijo in Ilirikom, 250-256, in Lalošević, Cum esset persecutio, passim. 
V letih 303/304 je nastal njegov najzgodnejši krščanski spis O božjem stvarjenju (De opificio Dei), ${ }^{11} \mathrm{v}$ katerem razpravlja o harmoniji narave in neumrljivosti duše. Z njim je skušal nekdanjega učenca Demetrijana vzpodbuditi, naj zaradi zemeljske blaginje ne zanemari duhovnih dobrin, in ga podučiti, da je človek po duši in telesu božje delo, ki ima razum zato, da se lahko brani in zaščiti.

V letih 304-311 je napisal svoje glavno delo Božji nauk (Divinae institutiones) v sedmih knjigah. Posvečeno je cesarju Konstantinu, k prvi izdaji, ki je nastala v času velikih preganjanj, pa je med letoma 322 in 324 pripravil še nekaj dodatkov oziroma predelav. Prvi dve knjigi Božjega nauka sta naravnani proti poganstvu, tretja proti filozofiji, četrta govori o Kristusu, peta in šesta o krščanski teologiji, sedma pa je posvečena poslednji sodbi in usodi duš. Božji nauk združuje apologetiko in neke vrste retorični učbenik, hkrati gre za prvo, čeprav ne celovito, predstavitev krščanske vere v latinščini, kot vzor pa so Laktanciju morda služili sistematični učbeniki rimskega prava in govorništva. Osrednja lika v tem delu sta filozof, ki se zavzema za poganstvo, ter sodnik, ki preganja kristjane in išče protislovja v Bibliji. Da bi temu oporekal, uporabi Laktancij filozofsko argumentacijo in se pri tem sklicuje na citate iz Biblije in antične poganske književnosti. Pri tem vključuje tudi grška besedila, na primer sibilinske oraklje in Platona, med latinskimi avtorji pa poleg Cicerona omenja predvsem Vergilija, Lukrecija in Ovidija. Slednji mu služi kot pričevalec proti poganstvu in za krščansko resnico. Med krščanskimi avtorji zavzema pri Laktanciju posebno mesto Minucij Feliks, pomemben se mu zdi tudi Tertulijan, nekoliko manj pa Ciprijan, češ da ni tako prepričljiv v argumentaciji. Namen spisa Božji nauk je dokazati, da je prevlada krščanstva nujna tudi s poganskega zornega kota. Ta cilj določa tudi izbor literarnih sredstev in samo formo v obliki učbenika. ${ }^{12}$

Epitome iz leta 314 je močno okrajšana verzija Božjega nauka, ki je nastala na željo nekega Pentadija. ${ }^{13}$ Ta spis prinaša tudi nekatere popravke izvirnika, navedeni so tudi novi citati iz Platona, Terencija, Vergilija, Horacija in Ovidija. Misel o propadu Rima, ki se v Božjem

11 Uvod z bibliografskimi podatki: Wlosok, L. Caecilius Firmianus Lactantius, $382-385$.

12 Gl. Wlosok, L. Caecilius Firmianus Lactantius, 385-392, in Albrecht, Geschichte, 1372-1373. Sodobna tekstnokritična izdaja: Heck in Wlosok, L. Caelius Firmianus Lactantius: Diuinarum institutionum libri septem.

13 Wlosok, L. Caecilius Firmianus Lactantius, 391-392. Kasnejši nastanek ok. leta 320 predvideva De Decker, Bibliographie raisonée, 117. 
nauku pojavlja na več mestih, je tu že opuščena, verjetno zaradi cesarja Konstantina, vsa grška besedila pa so prevedena v latinščino.

O Laktancijevih pismih Probu (štiri knjige), Severu in Demetrijanu (po dve knjigi), ki naj bi obravnavala različne teme, vemo samo to, da so ta besedila nastala, ko je Laktancij že postal kristjan - in da so bila precej dolgočasna (Damaz pri Hieronimu, Pisma 35.2). ${ }^{14}$

Laktancijev spis O jezi (De ira Dei) je nastal po Božjem nauku, ker se nanj večkrat sklicuje, njegova vsebina pa je prav tako apologetske narave. Krščansko spoznanje temelji na zavrnitvi čaščenja idolov, na veri v enega Boga in njegovem žrtvovanju v Kristusu. Človek je bil ustvarjen za vero, njegova dobra dejanja vzpodbudijo Boga k milosti, slaba pa k jezi. Jeza je čiščenje duše za obrambo pred grehom. Ni prepovedano jeziti se, ampak vztrajati v jezi. Živeti moramo tako, da si te božje jeze ne prislužimo. ${ }^{15}$

Poleg omenjenih del se Laktanciju pripisuje tudi pesnitev $O$ ptici feniksu (De ave phoenice), ki je Hieronim ne omenja, se pa njegovo ime pojavlja v treh rokopisih; kot avtorja ga omenja Gregor iz Toursa. ${ }^{16}$

Aprila 311 je Laktancij v Nikomediji doživel objavo Galerijevega tolerančnega edikta in izpustitev zaprtih kristjanov, junija 313 Licinijev prihod po zmagi nad Maksiminom Dajem, nato pa tudi objavo milanskega edikta, ${ }^{17}$ ki je zanj pomenil dejanski konec preganjanj. Kmalu zatem, morda še leta 313, bi torej lahko začel pisati delo O smrtih preganjalcev, nato dokončano poleti 316 ali še nekoliko prej v galski prestolnici Trierju. ${ }^{18}$ Ker je Licinij prikazan v še povsem pozitivni luči, bi bil terminus ante quem prvi spopad med Konstantinom in Licinijem, cibalska vojna (bellum Cibalense), ki se je končala $\mathrm{z}$ veliko Konstantinovo zmago. ${ }^{19}$

Toda ali je avtor spisa res Laktancij? Vprašanje je aktualno že več kot tristo let, povezano pa je predvsem $\mathrm{z}$ rokopisno tradicijo in šibko prisotnostjo spisa v antični književnosti. Preden se mu posvetimo, še na kratko o rokopisu, vsebini spisa, njegovi formi in literarni zvrsti.

14 Za Laktancijeva pisma, poganske in apokrifne spise gl. De Decker, Bibliographie raisonnée, v: De Decker, Bibliographie raisonnée, 56-66.

15 Wlosok, L. Caecilius Firmianus Lactantius, 392-394; Albrecht, Geschichte, 1373.

16 Wlosok, L. Caecilius Firmianus Lactantius, 398-401. O šibkih argumentih za Laktancijevo avtorstvo De Decker, Bibliographie raisonnée, 44-56.

$17 \mathrm{Za}$ Galerijev tolerančni edikt in milanski edikt, ki je prinesel versko svobodo tudi kristjanom na Vzhodu, gl. Bratož, Med Italijo in Ilirikom, 256-257.

18 Za uvod v problematiko, namen, čas nastanka in vsebino spisa gl. Wlosok, $L$. Caecilius Firmianus Lactantius, 377 in 394-398.

19 Za zapletena vprašanja kronologije in potek vojne gl. Bratož, Med Italijo in Ilirikom, 92-101. 
Ohranjeni rokopis z besedilom De mortibus persecutorum, ki ga je Étienne Baluze suvereno pripisal Laktanciju, je nastal v 11. stoletju v nekem galskem skriptoriju kot delo treh različnih prepisovalcev, s četrto roko pa so bila kasneje zapolnjena neberljiva mesta. ${ }^{20}$ Rokopis obsega 16 listov formata $24 \mathrm{~cm} \mathrm{x} \mathrm{16,5} \mathrm{cm,} \mathrm{zaradi} \mathrm{slabih} \mathrm{pogojev} \mathrm{hran-}$ jenja in kasnejših posegov na nekaterih delih precej poškodovanih, ${ }^{21}$ vsebuje pa tudi precej napak prepisovalcev, ki jih je v veliki meri odkril in popravil že Baluze, največkrat brez posebnega opozorila. ${ }^{22}$

Spis De mortibus persecutorum je posvečen nekemu Donatu, ki je preživel dolgoletni zapor in mučenje, a je vztrajal pri krščanski veri in tako postal njen izpovedovalec, confessor. Ob prikazu nesrečnih koncev najhujših preganjalcev skuša avtor pokazati, da se je Bog po pravici maščeval nad svojimi sovražniki in da je s tem svetu pokazal svojo moč in dal zgled tudi poznejšim dobam (1.2-7). V tem se morda zgleduje pri Drugi knjigi Makabejcev, s katero ima spis tudi sicer precej stičnih točk, prav tako s Konstantinovim govorom Oratio ad sanctorum coetum, ki ga omenja Evzebij v cesarjevi biografiji in ki je (v grškem prevodu) ohranjen v nekaterih rokopisih tega dela kot dodatek. ${ }^{23}$

Tendenca spisa De mortibus persecutorum je na podlagi sodobne zgodovine pokazati, da je Bog, ki ga častijo kristjani, najvišji Bog. Kot tak ima moč, da svoje nasprotnike kaznuje in svojim častilcem v dobro človeštva podeli uspeh in zmago. Po mnenju Antonie Wlosok je s to apologetsko težnjo spis neke vrste nadaljevanje spopada $\mathrm{z}$ ideologijo krščanstvu sovražnih oblastnikov v Laktancijevi peti knjigi Božjega nauka. Kot tak dokazuje sprevrženost uradne razglasitve kristjanov za brezbožne (impii) in sklicevanje preganjalcev na pobožnost (pietas) in pravičnost (iustitia). ${ }^{24}$

Spis je razdeljen v naslednje sklope in poglavja: ${ }^{25}$

Predgovor: božji triumf nad sovražniki Cerkve; nagovor izpovedovalca Donata (1)

Städele, Lactanz, 9; za nastanek med 1000 in $1161 \mathrm{gl}$. De Decker, L'historique d'une polémique, 121, op. 2.

21 Gl. Rougé, Remarques sur le premier folio, 30-35.

22 Brandt in Laubmann, De mortibus persecutorum, ix-xvii.

23 Gaetano Lettieri meni, da gre pri tem govoru za Laktancijev vpliv na cesarja, vsebuje namreč precej sorodnosti z njegovim glavnim delom Božji nauk; Lettieri, Lattanzio ideologo, 529.

24 Wlosok, L. Caecilius Firmianus Lactantius, 394.

25 Gl. Städele, Laktanz, 29-30 in Gordon, Lactantius, 63-65. 
Preganjalci kristjanov pred tetrarhi (2-6)

- Ustanovitev Cerkve; Neronovo preganjanje (2)

- Domicijanovo preganjanje (3)

- Decijevo preganjanje (4)

- Valerijanovo preganjanje (5)

- Avrelijanovo preganjanje (6)

Tetrarhi (7-9)

- Dioklecijan: kratka oznaka, politično delovanje, mdr. edikt o najvišjih cenah (7)

- Maksimijan: kratka oznaka, politično delovanje;

Konstancij (praeteritio) (8)

- Galerij: kratka oznaka, politično delovanje (9)

Preganjanje kristjanov pod tetrarhi (10-36)

- zadržani Dioklecijanovi začetki preganjanj (10)

- Galerijeva razširitev preganjanj, splošno preganjanje (11-15)

(a) ukrepi v Nikomediji (12-14)

(b) razširitev na celotno državo z izjemo Galije (15)

- Donat kot zmagovalec nad hudičem (16)

- Dioklecijanov padec (17-19)

- Galerijeva strahovlada (20-23)

- Galerijev propad, Maksimijanova smrt, Konstantinov vzpon (24-33)

- Galerijev tolerančni edikt (34)

- Donatova osvoboditev, Galerijeva smrt (35)

- Povezava Maksimina Daje z Licinijem, obnova preganjanj pod Maksiminom Dajo (36)

Strahovlada pod Maksiminom Dajo (37-41)

Spopadi med Maksiminom Dajo in Licinijem, Konstantinom in Maksencijem (42-51)

- Konstantin razglasi damnatio memoriae za Maksimijana,

Dioklecijanov dokončni propad in smrt (42)

- povezava Maksimina Daje in Maksencija (43)

- Konstantinova zmaga nad Maksencijem (44)

- Licinijeva zmaga nad Maksiminom Dajo (45-47)

- Milanski tolerančni edikt (48)

- smrt Maksimina Daje (49)

- Licinijevi umori (50-51)

Epilog: zahvala Bogu; nagovor Donata (52) 
Opis preganjanj pod tetrarhi kot osrednje teme spisa se začne z 10 . poglavjem. Kljub temu, da se konča šele v 36., s kratko omembo nadaljnjih preganjanj, ki jih je na Vzhodu izvajal Maksimin Daja, je tej temi dejansko posvečenih le osem poglavij: 10-15 (razširitev ukrepov na celotno cesarstvo) in 34-35 (Galerijev tolerančni edikt, Donatova osvoboditev iz ječe in Galerijeva strašna smrt). Tudi v tem delu zavzema največji obseg politična in vojaška zgodovina - Dioklecijanov padec (17-19), Galerijeva strahovlada in njegov propad ob sočasnem Konstantinovem vzponu (20-33). Sledi prikaz strahovlade Maksimina Daje (37-41) in spopada med njim in Licinijem na Vzhodu ter Konstantinom in Maksencijem na Zahodu (43-49), prekinjen z Dioklecijanovo smrtjo (42) in milanskim tolerančnim ediktom (48). Z Licinijevimi umori (50) božje sodišče sklene svoje delo - kot pravi avtor: »Tako je Bog premagal vse preganjalce svojega imena, da od njih ni ostalo niti deblo niti kakršnakoli korenina."

Slogovno spis nekoliko odstopa od Laktancijevih spisov filozofsko-apologetske narave, stavčne periode so tu krajše, manj ciceronske, kar je lahko povezano tudi s formo, namenom spisa in njegovim pričakovanim bralstvom. Vendar tudi v De mortibus persecutorum najdemo celo vrsto retoričnih figur, prijemov in stilističnih sredstev: aliteracijo, anaforo, antitezo in hiazem, apostrof, elipso, hiperbaton, paralelizem, podvojitve (npr. nefaria et cruenta ali pax iucunda et serena), ponovno postavljanje atributa na prvo mesto, kar poleg proznega ritma in zaključnih klavzul daje vsebini primerno vzvišen slog. ${ }^{26} \mathrm{O}$ dovršeni zgradbi spisa - Michael von Albrecht pravi, da gre pravzaprav za govor ${ }^{27}$ - priča tudi to, da se prvi stavek $\mathrm{z}$ nagovorom izpovedovalca Donata navezuje na zadnjega, saj pri obeh nastopa isti glagol (audio), ${ }^{28}$ Donat pa je nagovorjen tudi na dveh drugih izpostavljenih mestih, najprej ob razširitvi preganjanja na celotno državo z izjemo Galije (16.3) in ob njegovem koncu ob objavi Galerijevega tolerančnega edikta (35.1).

Spis v antični književnosti nima prave primere, ne prej ne pozneje. $\mathrm{V}$ zgodovinopisju je bil zato deležen različnih kategorizacij, med drugim kot krščanski pamflet in tendenčni spis, Konstantinov panegirik ali konstantinska propaganda ipd. Čeprav ne gre za običajno zgodovinopisno delo, vsebuje tako elemente poganskega kot krščanGordon, Lactantius, 77-297. Albrecht, Geschichte, 1374.

28 Mort. pers. 1.1: »Audivit dominus [...] Donate carissime«; 52.5: »Tu [...] Donate carissime, qui a Deo mereris audiri 
skega zgodovinopisja, ${ }^{29}$ prav tako tudi vrsto zgodovinskih podatkov in velja poleg Evzebijeve Cerkvene zgodovine kot glavni pisni vir za obdobje, ki ga obravnava. ${ }^{30}$

Da gre tu tudi za prikaz sodobne politične in vojaške zgodovine, kaže že sumarna obravnava preganjalcev pred tetrarhi, Nerona, Domicijana, Decija, Valerijana in Avrelijana, kot dovolj zgovoren dokaz, kako se je Bog nad svojimi sovražniki maščeval že tu na zemlji.3. Po drugi strani je avtor cesarje, ki so nastopali proti kristjanom ali so bili do njih zadržani in so veljali za dobre, na primer Trajana, Hadrijana in Marka Avrelija, povsem izpustil. Skušal je tudi dokazati sprevrženost tetrarhije, ki jo je uvedel Dioklecijan, nekoč mogočni cesar, ki je nazadnje končal kot nemočen starec in ki slednjič ni mogel zaščiti niti najožjih članov družine. ${ }^{32}$ Ukrepi tetrarhov, med njimi še posebej edikt o zamejitvi cen, drobljenje provinc, povečanje vojske, reorganizacija uprave $\mathrm{z}$ enormnim povečanjem državnega aparata, zakonodaja, prekomerna gradbena dejavnost in izčrpavanje provinc, vse to naj bi bilo zgrešeno, prineslo naj ne bi nobenega uspeha, le dodatno gorje in trpljenje. Po eni strani je šlo za propad Dioklecijanove politične ureditve, po drugi pa za zmago (in postopno prevlado) krščanske vere, ki jo je prinesel cesar Konstantin.

Ko želi tistemu, ki bi »želel pisati zgodovino«, popisati dogodke, ki jih je sam doživel, ko dogodke natančno datira, se drži časovnega sosledja, in dodaja tudi izvirne dokumente, se avtor približuje zvrsti »komentarja (commentarii), literarno nedodelani zbirki gradiva in zapiskov. $\mathrm{V}$ določeni meri se delo približuje tudi tradicionalni rimski historia, sočasni zgodovini, a tudi zgodovinski monografiji v Salustijevem slogu, predvsem zaradi osrednje teme, velikega preganjanja, pa prologa in epiloga z moralističnimi težnjami ter ekskurza o Donatovih preizkušnjah, ki jih je ta uspešno prestal (16). ${ }^{33}$

Odprto ostaja vprašanje avtorstva. Notica pri Hieronimu, da je Laktancij napisal delo De persecutione, stilna podobnost $\mathrm{z}$ drugimi Laktancijevimi spisi in drugi argumenti, ki jih je navedel Baluze - citati

Podrobneje o avtorjevem odnosu do krščanske in tradicionalne rimske historiografije Maver, De mortibus, 71-90.

Van Dam, Eusebius and Lactantius, 59-71.

O cesarjih preganjalcih v krščanskem zgodovinopisju gl. Maver, Preganjanja kristjanov.

2 Tudi leto Dioklecijanove smrti ni točno znano, kot skrajni letnici nastopata 311 in 318, najverjetnejša pa je 316; Carlà-Uhink, Diocleziano, 179-185.

Podrobneje o tem Maver, De mortibus persecutorum, 88-89. O možnosti, da je Donat povsem fiktivna oseba ali celo določeno širše občinstvo, ki ga Donat predstavlja, piše De Decker, Les circonstances historiques, 362. 
iz Vergilija, gentilno ime Caecilius, ki je poleg pogostejšega Caelius prav tako izpričano v Laktancijevih delih, in drugi - niso prepričali vseh. Trideset let kasneje je namreč benediktinski pater Denis-Nicolas Le Nourry v svoji izdaji kot avtorja navedel Lucija Cecilija, v dodani razpravi pa zastopal mnenje, da Laktancij ne more biti avtor takega pamfleta. ${ }^{34}$ Pozneje je bilo argumentov in zastopnikov teorije, da Laktancij ni avtor, še več. ${ }^{35}$ Med vidnejšimi predstavniki je bil tudi Samuel Brandt, najboljši poznavalec Laktancija na prelomu iz 19. v 20. stoletje, soizdajatelj njegovih spisov v zbirki CSEL, ki pa se je kasneje v recenziji odmevne Pichonove knjige Lactance: Études sur le mouvement philosophiques et réligieux sous le de Constanine (1901) dal prepričati v nasprotno (1903).

Po vrsti razprav in argumentov ene in druge strani je v preglednem sestavku o Laktanciju iz leta 1989 soizdajateljica moderne izdaje Božanskega nauka (2005-2011), Antonie Wlosok, dolgoletno diskusijo povzela z besedami, da se je mnenje, kako gre za spis De persecutione, ki ga omenja Hieronim, »o čemer se je dolgo dvomilo, danes povsem uveljavilo «.$^{36}$ Opozorila je tudi na izsledke raziskav, ki so pokazale, da je tudi Licinij prikazan v ugodni luč ${ }^{3}{ }^{7}$ in da tudi pri Maksimijanu in Maksenciju avtor ne podaja samo uradne Konstantinove verzije.

Toda zdi se, da vprašanje še ni povsem rešeno. Leta 2010 je Octavian Gordon, avtor filološkega komentarja k De mortibus persecutorum (2009), nasprotovanje Laktancijevemu avtorstvu, o čemer naj bi se »še vedno govorilo v privatnih krogih po univerzitetnih kuloarjih «, utemeljeval $\mathrm{z}$ rezultati podrobne besedne analize, posebej Laktancijeve uporabe besede iustitia. ${ }^{38}$ Njegov pregled nad kuloarji je bil očitno dober, kmalu zatem je vse postavila na glavo obsežna monografija z naslovom $D e$ mortibus persecutorum: Un libelle au service de la propagande constantinienne avtorjev Jeana Rougéja in Daniela De Deckerja iz leta 2013. Kot osnova za tekstnokritično izdajo latinskega besedila s komentarjem in prevodom, ki predstavlja osrednji del knjige, je služil neobjavljeni rokopis nekdanjega profesorja na Univerzi v Lyonu Jeana Rougéja (1913-1991), ki je v sedemdesetih letih pripravljal novo tekstnokritično izdajo, a je bil projekt kasneje ustavljen. Osnovna teza knjige je, da gre

Le Nourry, Dissertatio.

Gl. podrobneje Städele, Laktanz, 8-10; Spinelli, Lattanzio, 21-22, in De Decker, L'historique d'une polémique, 121-132 (z bibl. v op. 90 na str. 131).

6 Wlosok, L. Caecilius Firmianus Lactantius, 397. Podobno leta 2013 ugotavlja tudi Gaetano Lettieri, da ni več nobenega dvoma o Laktancijevem avtorstvu (Lettieri, Lattanzio ideologo, 46).

Gl. Søby Christensen, Lactantius the Historian, 27-32.

Gordon, Is De mortibus persecutorum an Orphan indeed? 27-31. 
za apokrifni in tendenčni spis v podporo konstantinski propagandi. Tudi tradicionalna datacija nastanka (313-316) je postavljena nekoliko širše, v leta med 312 in 324.

Kaj torej prinaša knjiga, katere vodilna teza je bila izrečena že večkrat, a se doslej ni uspela uveljaviti? Podrobneje obravnava dolgoletno polemiko o Laktancijevem avtorstvu dela De mortibus persecutorum s številnimi bibliografskimi podatki (str. 121-132), izsledke filoloških raziskav ob primerjavi s "pristnimi« Laktancijevimi spisi (str. 133-175), zgodovinske okoliščine nastanka (str. 361-399), primerjavo s Konstantinovim govorom Oratio ad sanctorum coetum (str. 401-411) ter pomen spisa za zgodovino (str. 413-459). Sledi še krajši povzetek in bibliografija, v dodatku pa sta dva prispevka o statistični metodi, uporabljeni za ugotavljanje Laktancijevega avtorstva. Besedila so s pomočjo računalnika »razbita « na besede in črke, kriteriji za ugotavljanje pristnosti so dolžina besed, pogostost uporabe glagola esse, delež samostalnikov in glagolov, delež vokalov in konzonantov, uporaba posameznih črk glede na njihovo mesto znotraj besede (Buchstabenschwerpunkt), številčna vrednost posameznih uporabljenih besed in standardno odstopanje pogostosti. Rezultati teh primerjav so ponazorjeni z grafi, pri čemer pri vseh vrednosti pri spisu De mortibus persecutorum precej odstopajo od ostalih primerjanih spisov (De opificio dei, De ira dei, Divinae institutiones, Epitome divinarum institutionum, De ave Phoenice). Tudi ti seveda ne kažejo povsem enotnih vrednosti, obstajajo določena medsebojna odstopanja, ki pa so kljub vsemu precej manjša. Tako avtor zaključi, da je glede na rezultate analize »težko vztrajati pri Laktancijevem avtorstvu spisa ${ }^{39}$

Kljub temu je treba predstavljeno ugotovitev obravnavati cum grano salis. Že naslednji prispevek namreč ocenjuje uporabljeno metodo - in presodi, da ne gre za formalno utemeljen dokaz, saj pri nobeni od izvedenih primerjav niso narejeni statistični izračuni, poleg tega pa je za primerjavo na voljo premalo besedil..$^{40}$ Vprašanje očitno ostaja odprto. 
IZDAJE IN PREVODI (IZBOR)

Baluze, Étienne. Liber de persecutione, sive de mortibus persecutorum, nunc primum editus ex vetustissimo codice ms bibliothecae Colbertinae. Pariz, 1679 (editio princeps).

Baluze, Étienne. Miscellaneorum liber secundus, hoc est collectio veterum monumentorum quae hactenus latuerant in variis codicibus ac bibliothecis. Pariz, $1679^{2}$.

Brandt, Samuel in Georgius Laubmann. Lucii Caecilii de mortibus persecutorum liber vulgo Lactantio tributus. CSEL 27/2, Dunaj: F. Tempsky, 1897.

Creed, J. L. Lactantius: De mortibus persecutorum. Oxford: Oxford University Press, 1984, 2. izd 1990.

Lucii Caecilii Firmiani Lactantii De mortibus persecutorum / Lucije Cecilije Firmijan Laktancije O smrtima progonitelja. Prevod Nenad Cambi in Bratislav Lučin. Split: Književni krug, 2005.

Lactance: De la mort des persécuteurs. Uvod, kritična izdaja, prevod in komentar Jacques Moreau. Sources Chrétiennes 39. Pariz: Cerf, 1954.

Laktanz: De mortibus persecutorum / Die Todesarten der Verfolger. Prevod Alfons Städele. Fontes Christiani 43. Turnhout: Brepols, 2003.

Lattanzio: Come muoiono i persecutori. Uvod, prevod in opombe Mario Spinello. Collana di testi patristici 180. Rim: Città Nuova, 2005.

Rougé, Jean, in Daniel De Decker. De mortibus persecutorum: Un libelle au service de la propagande constantinienne. Bibliotheca patristica Iassiensis 4. Iaşi: Editura Universităţii Alexandru Ioan Cuza, 2013.

O tvorenii božiem; O gneve božiem; O smerti gonitelej; Ėpitomy božestvennyh ustanovlenij - Lactantius, Lucius Caecilius Firmianus. Moskva: Izdatelstvo Olega Abyško, 2014².

LITERATURA

Albrecht, Michael von. Geschichte der römischen Literatur von Andronicus bis Boethius und ihr Fortwirken, 1-2. Berlin: De Gruyter, 2012. 
Bratož, Rajko. »Die diokletianische Christenverfolgung in den Donau- und Balkanprovinzen." V: Diokletian und die Tetrarchie: Aspekte einer Zeitenwende, ur. Alexander Demandt \& al., 115-140. Berlin: Walter de Gruyter, 2004.

- Med Italijo in Ilirikom: Slovenski prostor in njegovo sosedstvo v pozni antiki. Zbirka zgodovinskega časopisa 46. Ljubljana: Zveza zgodovinskih društev Slovenije, 2014.

Carlà-Uhink, Filippo. Diocletiano. Bologna: Società editrice il Mulino, 2019.

De Decker, Daniel. »Bibliographie raisonée sur la vie et l'oeuvre de L. Caelius Firmianus Lactantius."V: De mortibus persecutorum: Un libelle au service de la propagande constantinienne, ur. Jean Rougé in Daniel De Decker. Iaşi: Editura Universității Alexandru Ioan Cuza, 2013, 11-119.

— . "L'historique d'une polémique: Le De mortibus persecutorum attribué à Lactance."V: De mortibus persecutorum: Un libelle au service de la propagande constantinienne, ur. Jean Rougé in Daniel De Decker. Iaşi: Editura Universității Alexandru Ioan Cuza, 2013, 121-132.

— . "Les circonstances qui présidèrent à la composition du De mortibus persecutorum. V: De mortibus persecutorum: Un libelle au service de la propagande constantinienne, ur. Jean Rougé in Daniel De Decker. Iaşi: Editura Universității Alexandru Ioan Cuza, 2013, 361-399.

— . „Sommaire. V: De mortibus persecutorum: Un libelle au service de la propagande constantinienne, ur. Jean Rougé in Daniel De Decker. Iaşi: Editura Universității Alexandru Ioan Cuza, 2013, 461-462.

Demandt, Alexander. Die Spätantike: Römische Geschichte von Diocletian bis Justinijan 284-565 n. Chr. Handbuch der Altertumswissenschaft 3.6. München: C. H. Beck, 2. izd., 2007.

Gordon, Octavian. Lactantius de mortibus peresecutorum: Studiu filologic. Bukarešta: Editura Universtãţii din Bucureşti, 2009.

— . "Is De mortibus persecutorum an Orphan Indeed? « Studia Patristica 46 (2010), 27-31.

Heck, Eberhard, in Antonie Wlosok. L. Caelius Firmianus Lactantius, Diuinarum institutionum libri septem, Berlin: Teubner, 2005-2011.

Horacek, Helmut. »Bref aperçu critique et raisonné de la méthode ici décrite (note de lecture inédite rédigée par Dr. habil. Privat-Dozent Helmut Horacek, Université de Sarrebruck).« V: De mortibus persecutorum: Un libelle au service de la propagande 
constantinienne, ur. Jean Rougé in Daniel De Decker. Iaşi: Editura Universității Alexandru Ioan Cuza, 2013, 487-488.

Kraft, Heinrich. »Une méthode statistique appliquée au De mortibus persecutorum de Lactance et pourtant sur la critique d'attribution de ce texte à ce Père de l'Eglise par $(\dagger)$ Heinrich Kraft (Étude manuscrite inédite)."V: De mortibus persecutorum: Un libelle au service de la propagande constantinienne, ur. Jean Rougé in Daniel De Decker. Iaşi: Editura Universității Alexandru Ioan Cuza, 2013, 473-485.

Kuhoff, Wolfgang. Diokletian und die Epoche der Tetrarchie: Das römische Reich zwischen Krisenbewältigung und Neuaufbau (284-313 n. Chr.). Frankfurt na Majni: Lang, 2001.

Lalošević, Vesna. Cum esset persecutio: Dioklecijanovo doba na području između Akvileje i dunavskog limesa u mučeničkim legendama. Split: Književni krug, 2018.

Lettieri, Gaetano. »Lattanzio ideologo della svolta costantiniana." V: Costantino I: Enciclopedia Costantiniana sulla figura e l'immagine dell'imperatore del cosidetto editto di Milano 313-2013, 2. 45-57. Rim: Istituto della Enciclopedia italiana, 2013. Maver, Aleš. »De mortibus persecutorum med krščansko in pogansko historiografijo." Keria 6.2 (2004), 71-92.

_ . »Preganjanja kristjanov in cesarji preganjalci pri latinskih krščanskih zgodovinarjih 4. in 5. stoletja. K Keria 10.1 (2008), $53-76$.

- Religiosi et profani principes: Rimski cesarji od Avgusta do Teodozija v latinskem krščanskem zgodovinopisju 4. in 5. stoletja. Maribor: Zgodovinsko društvo dr. Franca Kovačiča, 2009. Roberto, Umberto. Diocleziano: Il principe carismatico e autoritario, salvatore dell'impero, che abdicò in cerca di pace e silenzio. Rim: Salerno Editrice, 2016.

Rougé, Jean. »Remarques sur le premier folio du manuscrit du De mortibus persecutorum. "Revue des études augustiniennes 30 (1984), 30-35.

— in Daniel De Decker. De mortibus persecutorum: Un libelle au service de la propagande constantinienne. Iaşi: Editura Universității Alexandru Ioan Cuza, 2013.

Søby Christensen, Arne. Lactantius the Historian. København: Museum Tusculanum Press, 1980.

Van Dam, Raymond. »Eusebius and Lactantius on Constantine in 312-313." V: Constantine: Religious Faith and Imperial Policy, ur.

A. Edward Siecienski, 59-74. London: Routledge, 2017. 
Wlosok, Antonie. »L. Caecilius Lactantius. V: Restauration und Erneuerung: Die lateinische Literatur von 284 bis 374 n. Chr., ur. Reinhard Herzog. Handbuch der Altertumswissenschaft 8.5. München: Beck, 1989, 375-404. 


\section{IZVLEČEK}

Spis z naslovom Knjiga Lucija Cecilija izpovedovalcu Donatu o smrtih preganjalcev (De mortibus persecutorum) je ohranjen v enem samem rokopisu iz 11. stoletja, odkritem leta $1778 \mathrm{v}$ samostanski knjižnici v Moisacu. Ob prvi objavi (1779) ga je Étienne Baluze pripisal krščanskemu piscu in učitelju retorike Laktanciju (ok. 250-ok. 325), najbolj znanemu po prvi celoviti obravnavi krščanske vere, spisu Božji nauk (Divinae institutiones), a kmalu so se pojavili dvomi o njegovem avtorstvu. Tako po formi kot po obravnavani temi, strahotnih koncih cesarjev preganjalcev, ki jih je Bog strogo kaznoval za njihove zločine, spis $\mathrm{v}$ antični književnosti nima prave primere. Zato je bil deležen različnih opredelitev kot krščanski pamflet, Konstantinov panegirik, konstantinska propaganda ipd. Forma je izrazito retorična, vsebuje tudi elemente krščanskega in poganskega zgodovinopisja in hagiografije, zgleduje se po judovski in antični tradiciji, v njem so opazne sorodnosti z Drugo knjigo Makabejcev in Konstantinovim govorom Oratio ad sanctorum coetum. Po vrsti razprav in člankov za in proti Laktancijevemu avtorstvu, ko se je zdelo že, da dvomov ni več, je leta 2013 izšla knjiga Jeana Rougéja in Daniela de Deckerja z obnovljeno tezo, da je spis služil konstantinski propagandi in je nastal na pobudo cesarja, podkrepljeno s temeljito študijo drugih Laktancijevih del, in argumenti, oprtimi tudi na izsledke računalniško pripravljenih analiz. Zdi se, da vprašanje ostaja odprto.

KLJUČNE BESEDE: Laktancij, De mortibus persecutorum, panegirik, propaganda, Konstantin 


\section{ABSTRACT}

The Book of Lucius Caecilius to Donatus on the Deaths of the Persecutors (De Mortibus Persecutorum) is preserved in a single 11th-century manuscript, discovered in 1778 in the monastery library in Moisac. In his editio princeps (1779), Étienne Baluze attributed it to the Christian rhetor Lactantius (ca. 250 - ca. 325), best known for his comprehensive discussion of the Christian faith, The Divine Institutes (Divinae Institutiones). Doubts about its authorship soon arose. Both in form and subject matter, the terrible deaths of the persecuting emperors, severely punished by God for their crimes, the text has no real parallel in late-antique literature. It was variously described as a Christian pamphlet, Constantine's panegyric, Constantine's propaganda etc. The form is distinctly rhetorical; it also contains elements of Christian and pagan historiography and hagiography, it is inspired by Jewish and ancient tradition, and there are noticeable similarities with the Second Book of the Maccabees and Constantine's Oratio Ad Sanctorum Coetum. After a series of debates and articles regarding Lactantius' authorship, when it seemed that there were no more doubts, a book by Jean Rougé and Daniel de Decker was published in 2013, revisiting the thesis that the work served Constantine's propaganda and was created at the emperor's initiative. The book was supported by a thorough study of other Lactantius' works, as well as arguments based on the results of computer-aided analyses. The question seems to remain open.

KEYWORDS: Lactantius, De Mortibus Persecutorum, panegyric, propaganda, Constantine 